\title{
Biocontrol of Xanthomonas axonopodis causing bacterial spot by application of formulated phage
}

\author{
Tewfike T.A. ${ }^{1}$ and Shimaa M. Desoky ${ }^{2}$ \\ ${ }^{1}$ Botany Department (microbiology), Fac. of Agriculture, Benha University, Egypt. \\ ${ }^{2}$ Botany Department, Faculty of Science, Suez University, Egypt.
}

\begin{abstract}
Currently phages used as an alternative method for biocontrol plant pathogenic bacteria. However, the efficacy of phage is greatly reduced due to its short longevity on leaf surface of plant. Formulated phages [0.5\% corn flour (CF) and $0.5 \%$ skim milk (SM)] significantly increased phage longevity on leaves surface were tested in greenhouse and open field trials during the growing season 2014. The leaves of pepper showed halo blight symptoms were tested for the presence of phages specific of Xanthomonas axonopodis by spot test. The phages were isolated by single plaque assay from the infected pepper leaves with spots symptoms. The isolated phages produced plaques with 3 to $5 \mathrm{~mm}$ diameters translucent spreading halo. The morphological phages particles were isometric head with 70 to $75 \mathrm{~nm}$ across with short contractile tails. The formulated isolate phages (CF and SM) were reduced the disease severity to 20.5 and $18.3 \%$ under greenhouse and 24.5 and $32.2 \%$ under open field conditions respectively, compared with unformulated phages. While, copper mancozeb reduced the disease severity to 45.3 and $39.5 \%$ (greenhouse) as well as 60.7 and $35.4 \%$ (open field) respectively. The skim milk and corn flour were applied for disease control trials and increased the phage longevity at 20 to $50 \mathrm{hrs}$ and phage population $10^{6}, 10^{5}$ (skim milk) to $4 \times 10^{4}$ and $5 \times 10^{3}$ plaque forming unit (PFU) in greenhouse and open field respectively . These formulated phages may be useful as a tool to efficient biocontrol of halo blight disease.
\end{abstract}

Key wards: biological control, bacteriophages, plant bacteria pathogens; Xanthomonas axonopodis

\section{Introduction}

Management of plant diseases may be achieved by integration of cultural practices, chemical control, acquired systemic resistance and resistance breeding. Additionally, appearance of antibiotic and cupper resistant bacterial strains in the field hindered the efficacy of chemical control (Marco and Stall 1983). If weather conditions are favorable for disease development, there are no adequate control measures to manage the disease (Kucharek, 1994).Several alternative control methods have been investigated in recent years, systemic acquired resistance (SAR) inducers, such as acibenzolar methyl and harpin, have been shown to be active against bacterial disease of tomato (Louws, et al., 2001) and their use in control of bacterial spots is the subject of ongoing research (Obradovic et al., 2002). Biological control of the disease has been attempted by using a nonpathogenic, Ps. putida B 56 antagonistic Ps. syringae_Cit 7 (Wilson et al., 1997). Another approach for biological control is the use of bacterial viruses to control bacterial diseases. Phages have long been proposed as plant disease control agents and have been used in several plant bacterium pathosystem (Zaccarodelli et al., 1992 and Balogh and Jones, 2003). Additionally, phages treated plants were found to be significantly more vigorous than copper treated and untreated ones, and they yielded significantly more extra-large fruits as well. However, Eman and Afaf (2014) noted that the phages application were in effective for controlling of bacterial halo blight and speculated that phage endurance was significantly reduced (Jones and Pernezny ,2003).

Viruses are very fragile and can't reside long on plant foliage because they are quickly eliminated by harmful environmental factors such as rain and sunlight UV (McGuire, et al. 2001). Therefore, the need arose to develop for mutations and/or change the application strategy, such as time of application in order to protect phage particles from harmful environmental factors. The accordingly enhanced residual activity of the phages could lead to increase efficacy of phage treatments and to a more convenient application schedule (Balogh, and Jones, 2003).

The objective of this study was to investigate in greenhouse and open field experiments whether the use of selected formulations enhanced the efficacy of phage treatment for controlling bacteria halo blight of pepper plants.

\section{Materials and methods}

Plant bacterial pathogen 
Three isolates of Xanthomonas axanopodis was kindly provided by plant pathology Dept.,Fac. of Agric.,Ain Shams Univ. Cairo, Egypt. The bacteria pathogen was isolated from symptomatic pepper (Capsicum spp.) leaves with bacterial spots cultivated in field experimental field Fac. of Agric. Ain- Shams University. Egypt. The bacterial isolate was streaked on nutrient agar medium in glass Petri dishes and incubated at $28{ }^{\circ} \mathrm{C}$ for $48 \mathrm{hrs}$. The bacterial growth were collected and washed with the saline solution $(\mathrm{NaCl} 0.85 \%)$. The suspensions were shacked by magnetic stirrer for $15 \mathrm{~min}$. The concentration of bacteria isolates were counted by the most portable number adjusted at about mean density of $10^{8}$ colony forming unit (CFU). Isolation and identification processes were carried out according to Fourine (1998) .The colonies of Xanthomonas axonopodis subjected to further characterization to identify the isolates as the standard procedures and confirmed using VETIC kit (Bio Mèrieux, France)

\section{Bacteriophages}

The infected pepper leaves showing spots symptoms were cut to small pieces and crushed in sterilized water $(2: 1 \mathrm{w} / \mathrm{v})$ plus sterilized 3 drops of tween 80 per flask. The flasks were shacked on a rotary shaker for $72 \mathrm{hrs}$ at room temperature on $3000 \mathrm{rpm}$ for 20 min. The flasks were inoculated with Xanthomonas axonopodis at log phase culture approximately 5x107 $\mathrm{CFU} / \mathrm{ml}-1$ in nutrient glucose broth $(2.0 \mathrm{~g} / \mathrm{L}$ yeast extract and $2.5 \mathrm{~g} / \mathrm{L}$ glucose).The flask cultures were incubated and shaken continuity for overnight at $28^{\circ} \mathrm{C}$ in shaking incubator. Bacterial cell and leaves debris were removed by centrifugation at $6000 \mathrm{rpm}$ for $15 \mathrm{~min}$. The produced phages suspension was tittered by plaque assay method to make certain there were at least $108 \mathrm{PFU} / \mathrm{ml}$. The phage mixtures consisted of two phage isolates and had an approximate final titer of 1 x $1010 \mathrm{PFU} / \mathrm{ml}$. The phages mixtures were stored in $2 \mathrm{ml}$ Ependorf tube at $4^{\circ} \mathrm{C}$ in complete darkness.

\section{Phages morphology}

Transmission electron microscope (TEM) was used to detect phages typing of Xanthomonas axonopodis. The phages were visualized using negative staining method with $1 \%$ aqueous uranyl acetate. The grids were air dried and were examined by TEM (JEOL JEM - 1010 Electron microscope) in (The Regional Center for Mycology Al-Azhar Univ.) according to Heringa et al. (2010).

\section{Phag formulations}

Two formulations were used included:(a) $0.5 \%$ pregelatinized corn flour and $0.5 \%$ sucrose (PCF) (b) $0.75 \%$ skim milk powder and $0.5 \%$ sucrose (skim
milk),(Balogh, 2002), as a formulated phages under greenhouse and field trails conditions.

Phage infectivity: Xansomonas axonopodis was suspended in sterile distilled water to a density of $10^{7}$ $\mathrm{CFU} / \mathrm{ml}^{-1}$ and inoculated on nutrient agar plates. The phage drop $(20 \mu \mathrm{l})$ of each isolate was over layered on agar. The plates were incubated at $28{ }^{\circ} \mathrm{C}$ overnight. Clear confluent lysis and turbid confluent lysis were recorded with two isolets only as positive result, while extremely faint zones were considered negative result (Eayre, et al., 1995

\section{Biocontrol experiment \\ Greenhouse experiment}

Pepper seeds were cultivated in pots $(20 \mathrm{cmQ})$ containing autoclaved sterilized soil and maintained in greenhouse at 23 to $28^{\circ} \mathrm{C}$, fertilized and watered as needed. Three seedlings per pot and ten pots as a replicates for each treatment was done. Xanthomonas axonopodis growth was removed from nutrient agar plates $24 \mathrm{hrs}$ post inoculation and suspended in sterile water and adjusted to $\mathrm{A}_{660}=0.5$ by spectrophotometer which approximately $10^{8} \mathrm{CFU} / \mathrm{ml}^{-}$ ${ }^{1}$.Three leaves of each seedling were inoculated with bacterial suspension using a hand-hold plastic sprayer until completely wet. The suspension phage mixtures was adjusted by spectrophotometer which approximately $1 \times 10^{10} \mathrm{PFU} / \mathrm{ml}$ and used as a biocontrol agent. Control plants were sprayed with tap water, as well as another plant was treated with copper mancozeb (Fungicide). Inoculated plants were sealed within a plastic bag (two hour post inoculation) in order to maintain high relative humidity. The plants were kept in growth chamber at $28^{\circ} \mathrm{C}$ and $16 \mathrm{hrs}$ photoperiod for $48 \mathrm{hrs}$ (Fourie, 1998). The plastic bags were removed and the plants were transferred to the greenhouse where they arranged in a completely randomized block design. The treatments and their constitution are shown in Table (A).

\section{Field experiment:}

Also, was carried out at spring growing season 2014. Treatments used in the field experiment are shown in Table (A). Three replicates of plots were implemented for each treatment and the plots were arranged in a randomized complete block design. Each plot consisted of 10 pepper plants. The pepper seeds were cultivated according to standard horticultural methods (Ministry of Agriculture). Xanthomonas axonopodis isolates suspensions $\left(10^{8}\right.$ $\mathrm{CFU} / \mathrm{ml}^{-1}$ ) mixed with $0.05 \%$ tween 80 and misted on pepper leaves in middle_of each plot using plastic sprayer. Mixed phages $\left(1 \times 10^{10} \mathrm{PFU} / \mathrm{ml}\right)$ treatments were applied twice weekly in the evening. 
Copper mancozeb treatment was applied one week from cultivation or sowing. The treatments used in

the field experiment are shown as follow:

Table (A) Layout of treatment applied in greenhouse and field experiments with amount based on 1liter spray $\max$

\begin{tabular}{lcccccc}
\hline \multicolumn{1}{c}{ Treatments } & X.axonopodis $(\mathrm{ml})$ & $\begin{array}{c}\text { Skim milk } \\
(5 \%)\end{array}$ & $\begin{array}{c}\text { Corn } \\
\text { flour } \\
(5 \%)\end{array}$ & Tween 80 & $\begin{array}{c}\text { Phages } \\
\text { mixture } \\
(\mathrm{ml})\end{array}$ & $\begin{array}{c}\text { Mancozeb } \\
(\mathrm{g} / \mathrm{l})\end{array}$ \\
\hline $\begin{array}{l}\text { unformulated } \\
\text { healthy } \\
\text { unformulated } \\
\text { inoculated }\end{array}$ & $\mathrm{X}$ & & & & $\mathrm{X}$ \\
$\begin{array}{l}\text { Formulated skim } \\
\text { milk }\end{array}$ & $\mathrm{X}$ & $\mathrm{X}$ & $\mathrm{X}$ & $\mathrm{X}$ & $\mathrm{X}$ & \\
$\begin{array}{l}\text { Formulated corn } \\
\text { flour }\end{array}$ & $\mathrm{X}$ & & $\mathrm{X}$ & $\mathrm{X}$ & $\mathrm{X}$ & \\
\hline Mancozeb & $\mathrm{X}$ & & $\mathrm{X}$ & & $\mathrm{X}$ \\
\hline
\end{tabular}

\section{Determinations}

Disease severity was carried out two times during growing season. Two types of disease severity were performed. Determination of disease severity was estimated according to Weller (2007) and calculated the spot areas under the disease progress curve (AUDPC) according to Shaner and Finney, (1977). Also, lesions number in leaves (10 leaves per treatment).

Determination of phage titer was according to Balogh and Jones, (2003) during growing season at twice leaves sample were collected from all treatments in the day following the morning application at the afternoon and evening. Each sample consisted of 10 leaves that were located on exposed positions of the plant. The leaves were put in the plastic bags and kept in ice box and weighted and poured $100 \mathrm{ml}$ deionized water in bag. The bags were shaken on shaker for $20 \mathrm{~min}$ and $1 \mathrm{ml}$ of rinsing was transferred to $2 \mathrm{ml}$ Ependorf tube and $100 \mu \mathrm{l}$ chloroform was added. The tube were shaken on vortex for $30 \mathrm{~min}$. The tubes were centrifuged in Ependorf at $6000 \mathrm{rpm}$ for $15 \mathrm{~min}$, then $500 \mu \mathrm{l}$ of supernatant was put in sterile Ependorf tube. The supernatant was serial diluted for enumeration of the phage titer. X. axonopodis cells 24 hrs old culture were scraped from the agar plates and suspended in sterile water. A $100 \mu \mathrm{l}$ of phage suspensions mixed with $100 \mu \mathrm{l}$ of bacterial suspension and placed on sterile Petri dish. The nutrient agar medium heated to $45-50^{\circ} \mathrm{C}$ was added to the mixture and medium was swirled in Petri dish to facilitate mixing of bacterial cells and phage particles. The plate was incubated at $28^{\circ} \mathrm{C}$ for 48 hrs until the plaques became visible. The plaques were counted at the suitable dilutions. The phage titer was calculated as PFU per gram of leave tissues by the following equation.
Phage titer $=$ plaque number $\times 1.000 /$ (weight of sample bag - weight of empty) bag.

\section{Statistical analysis}

The results of each sample were transformed using $\log$ transformation

$[\mathrm{z}=\log 10(\mathrm{Y}+1)]$ and then subjected to ANOVA analysis

\section{Results}

Bacterial identification: Three isolates only of $X$. axonopodis isolated from symptomatic pepper leaves spots were identified based on morphological and biochemical tests. Two isolates only revealed negative results with oxidase test, mannitol, sorbitol and inositol as sole carbon sources and positive results with leaven. The isolates were short rods and negative gram staining. The isolates produced brown diffusible pigment on king B medium. Based on morphological and biochemical tests two isolated bacteria were identified as EG1and EG2. The isolated $X$. axonopodis confirmed by VETIC Kit.

\section{Phages propagation}

Crude phage suspension prepared from infected leaves of pepper plants and assayed by the over layer technique. Phage isolates were produced different plaque types where regular, irregular circular form clear center and turbidity center with size 3 to $5 \mathrm{~mm}$ diameter translucent spreading halo (Fig. A). The phage isolates distinct host specificity when tested with two pathogenic $X$. axonopodis. The specific phage was quantitatively assayed by plaque assay and purified by abtained a single plaque of lysate type. Single plaque isolate was picked up and put 2 $\mathrm{ml}$ of $X$. axonopodis broth culture $\left(1 \times 10^{8} \mathrm{CFU} / \mathrm{ml}\right)$ and macerated then incubated. Specific phage isolates were reacted with $3 \mathrm{X}$. axonopodis isolates 
with different type of lysis except one isolate of bacteria did not developed plaques. The produced plaques by specific phages isolates [Clear confluent lysis, turbid confluent with large and small circular with halo and without halo) were mixed for using as biocontrol agents $\left(4.5 \times 10^{10} \mathrm{PFU} / \mathrm{ml}\right)$. Electron microscope of phage particles revealed that phages are short, curled, non-contractile tail. The phage particles have an isometric head with different diameter size 70 to $75 \mathrm{~nm}$ and short contractile tail (Fig.A).

\section{Biocontrol in greenhouse}

Spraying of pepper plants with phage postinoculation with $X$. axonopodis isolates showed reduction of disease severity and lesion spots either in individual X.axonopodis EG or mixture of isolates EG1, EG2 treatments. On the other hand, treating with formulated phages showed significant reduction of disease severity and lesion spots compared with both unformulated phages and copper mancozeb application. However, skim milk formulation achieved the greatest reduction in disease severity to 23.5, 20.3 and $18.3 \%$ and corn flour formulation to 27.2, 28.5 and $20.5 \%$ for $X$. axonopodis EG isolates EG1, EG2 and their mixture, respectively (Table 1 and Fig.1) while mancozeb, application reduced the disease severity to $30.5,35.5$ and $39.5 \%$ and unformulated phages to $52.3,45.5,45.3 \%$ compared with control since they were 75.5, 72.5, 85.5\% respectively (Table 1 and Fig.2). As well as, formulated phages showed reduction in No. of spots (Table1 and Fig.1). The skim milk and corn flour formula without phages did not reduce the disease severity and lesion halo numbers.

\section{Biocontrol in open field}

In April, 2014 growing season of pepper plants the formulated phages caused significant reduction in both disease severity and halo lesion blight compared with unformulated phages, mancozeb and untreated control treatments (Table 2 and Fig.2). According to the area under the disease progress curve (AUDPC), the skim milk and corn flour formulated phages were the most effective in disease control being significantly more efficient than both unformulated phages, and copper mancozeb application. The unformulated phage treatment significantly reduced the disease severity compared with untreated control and achieved a level of control similar to copper mancozeb application treatment (Table2 and Fig.2), whereas, for both skim milk and corn flour formulations significantly further increased the efficacy of phage treatment. The skim milk formulated phages was significantly more effective for disease severity reduction with 25.0, 20.2, 19.5\% than corn flour formulated phages with $35.2,30.3$, $32.5 \%$ for $X$. axonopodis EG 1, 2 and their mixtures, respectively (Table, 2).
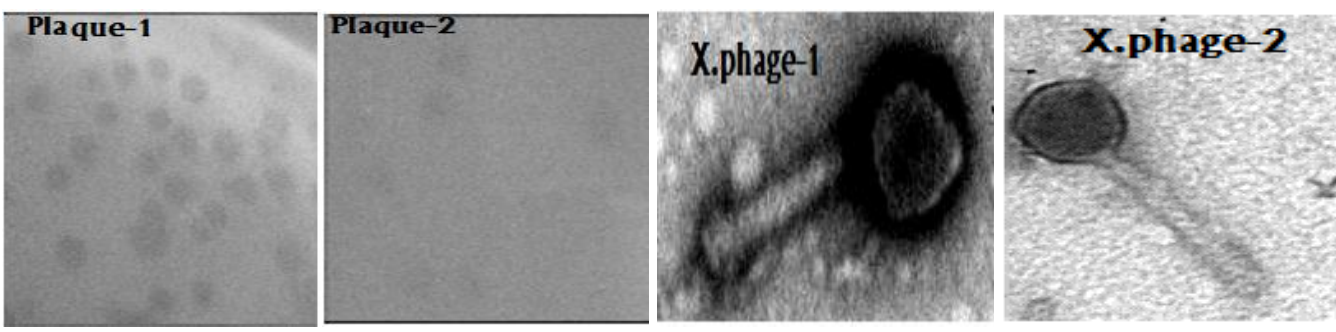

Fig. A: Electrophotogram illustrated negatively stained distinguished morphology of Xanthomonas phage particles and showing different two types of plaque morphology.

Table 1. Disease severity and halo blight lesion of infected pepper plants sprayed with formulated phages under greenhouse.

\begin{tabular}{|c|c|c|c|c|c|c|c|}
\hline \multirow{2}{*}{$\begin{array}{l}\text { Bacterial } \\
\text { isolates } \\
\text { Treatments }\end{array}$} & \multicolumn{2}{|c|}{$\begin{array}{c}\text { X. axonopodis EG } \\
1 \\
\end{array}$} & \multicolumn{2}{|c|}{$\begin{array}{l}\text { X. axonopodis EG } \\
2 \\
\end{array}$} & \multicolumn{3}{|c|}{$\begin{array}{c}\text { Mixture of isolate } \\
\text { EG1, EG2 }\end{array}$} \\
\hline & $\mathrm{DS} \%$ & $\begin{array}{l}\text { No. of } \\
\text { halo }\end{array}$ & DS\% & $\begin{array}{c}\text { No. of } \\
\text { halo }\end{array}$ & $\mathrm{DS} \%$ & $\begin{array}{l}\text { No. of } \\
\text { halo }\end{array}$ & AUDPC \\
\hline Untreated control & 75.5 & 10.5 & 72.5 & 10.5 & 85.5 & 10.5 & 52.1 \\
\hline Unformulated phages & 52.3 & 4.2 & 45.5 & 4.5 & 45.3 & 3.3 & 48.4 \\
\hline Formulated phages & & & & & & & \\
\hline Skim milk & 23.5 & 1.2 & 20.3 & 1.9 & 18.3 & 1.2 & 23.8 \\
\hline Corn flour & 27.2 & 2.8 & 28.5 & 2.1 & 20.5 & 1.5 & 25.5 \\
\hline Copper mancozeb & 30.5 & 2.9 & 35.5 & 2.9 & 39.5 & 2.9 & 28.3 \\
\hline
\end{tabular}

DS = Disease severity

No.of spots $=$ number of spot lesions per leaf.

AUDPC $=$ Area under the disease progress curve. 


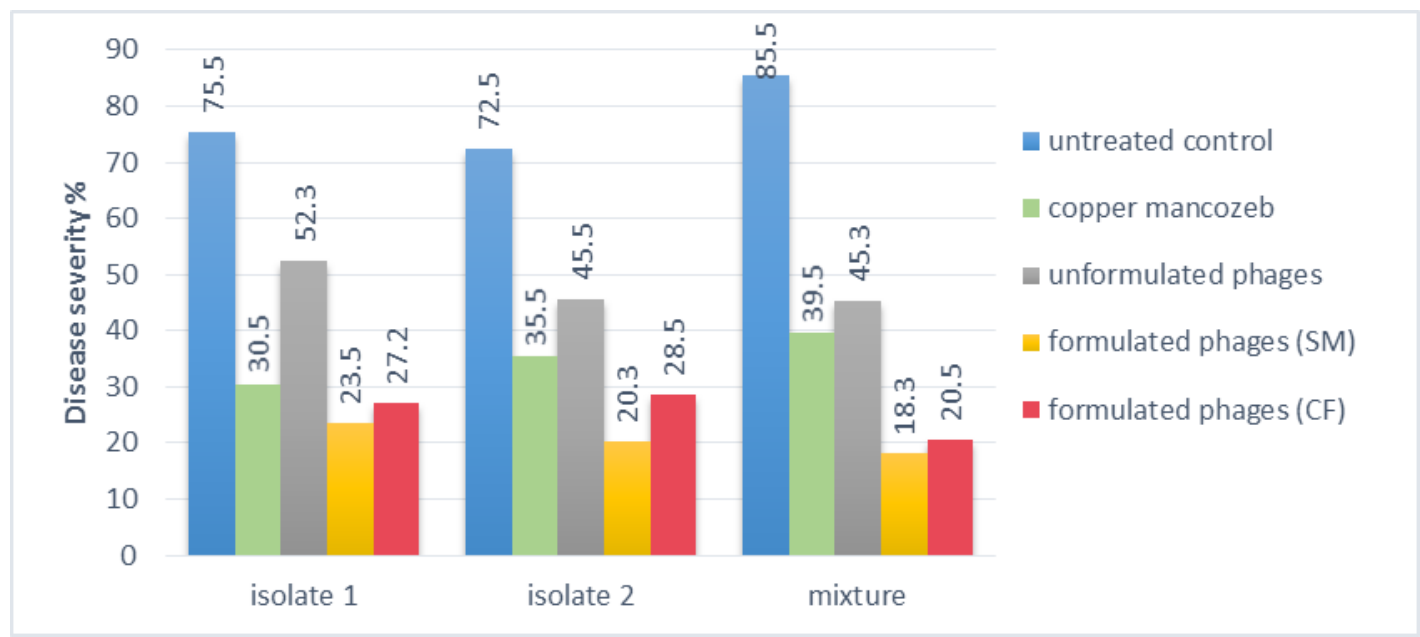

Fig.1: Disease severity percentage of pepper plant infected with $X$. axonopodis EG isolates under greenhouse conditions

Table 2. Disease severity and spot lesions of infected pepper plants sprayed with formulated phages under open field.

\begin{tabular}{lccccccc}
\hline \multirow{2}{*}{$\begin{array}{l}\text { Bacterial } \\
\text { isolates }\end{array}$} & \multicolumn{3}{c}{$\begin{array}{c}\text { X. axonopodis isolate } \\
\text { EG1 }\end{array}$} & \multicolumn{2}{c}{$\begin{array}{c}\text { X. axonopodis isolate } \\
\text { EG2 }\end{array}$} & \multicolumn{3}{c}{$\begin{array}{c}\text { Mixture of isolate } \\
\text { EG1, EG2 }\end{array}$} \\
\cline { 2 - 8 } & DS\% & $\begin{array}{c}\text { No. of } \\
\text { halo }\end{array}$ & DS\% & $\begin{array}{c}\text { No. of } \\
\text { halo }\end{array}$ & DS\% & $\begin{array}{c}\text { No. of } \\
\text { halo }\end{array}$ & AUDPC \\
\hline $\begin{array}{l}\text { Untreated control } \\
\text { unformulated }\end{array}$ & 80.2 & 12.5 & 85.2 & 15.3 & 85.5 & 25.7 & 62.9 \\
phages & 70.3 & 6.2 & 65.5 & 7.1 & 66.7 & 7.5 & 50.5 \\
$\begin{array}{l}\text { Formulated phages } \\
\text { Skim milk }\end{array}$ & & & & & & & \\
Corn flour & 25.0 & 3.0 & 20.2 & 3.1 & 19.5 & 3.2 & 25.9 \\
\hline Copper mancozeb & 45.2 & 4.5 & 30.3 & 4.2 & 32.2 & 5.5 & 45.2 \\
\hline (AUDPC): Area under the disease progress curve & & & & & & 9.5 & 49.2 \\
\hline
\end{tabular}

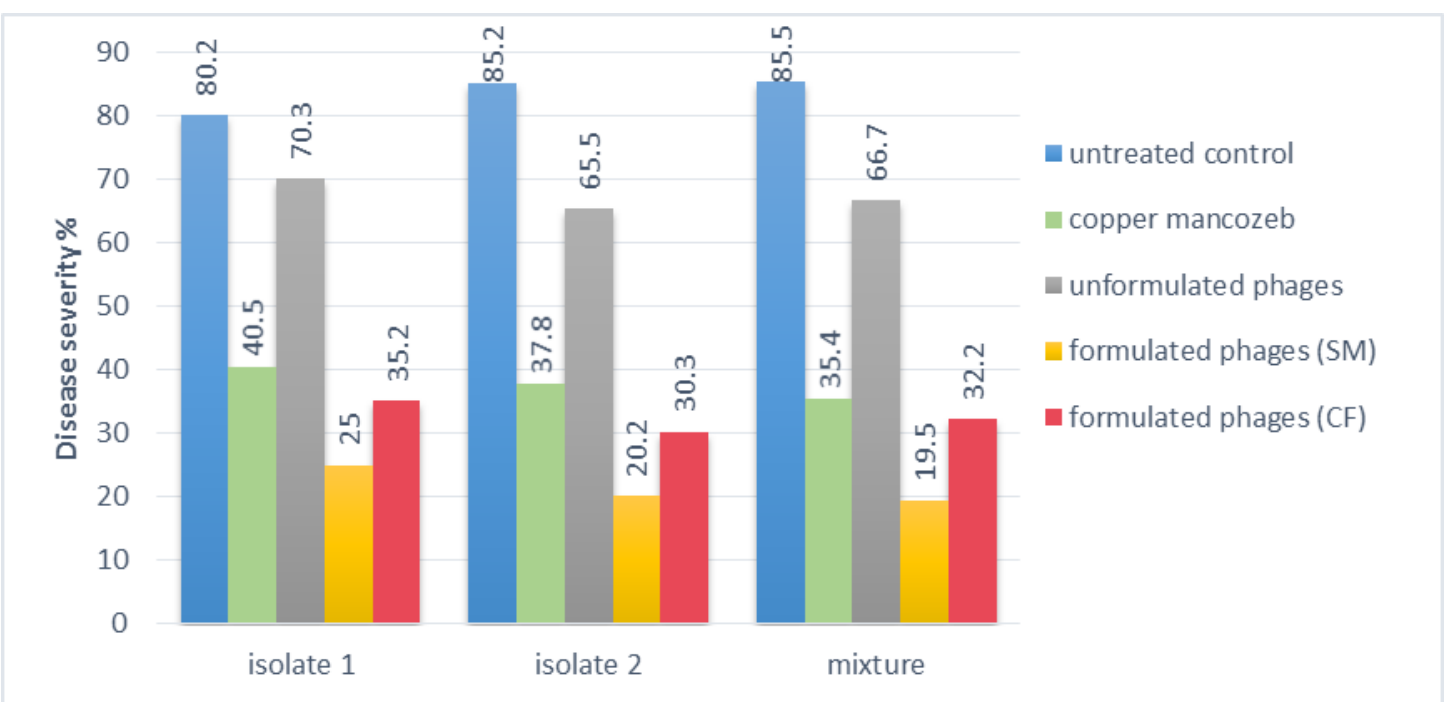

Fig. 2: Disease severity percentage of pepper plant infected with $X$. axonopodis EG isolates under open field conditions. 


\section{Longevity of formulated phages in field}

The change in phage populations were determined during growth plants in open field. $X$. axonopodis anti-phages was not present in the field, due to the antagonistic effect. The changes in phages reflected as phages populations appeared in a host- free environment. On the other hand, unformulated phage populations were quickly reduced and practically eliminated $36 \mathrm{hrs}$ with in and $48 \mathrm{hrs}$ after spraying (Fig. 3). The skim milk formulated phages decreased the reduction rate of phage populations at 40 to 60 hrs. The corn flour formulated phages decreased the reduction rate of phage populations at 20 to $60 \mathrm{hrs}$. On the other hand, phage formulations were performed uniformly in greenhouse and open field assessments, showing the reduction rate and contributing to approximately $10^{6} \mathrm{PFU} / \mathrm{ml}$ after phages spraying compared with phages spraying without protective formulation

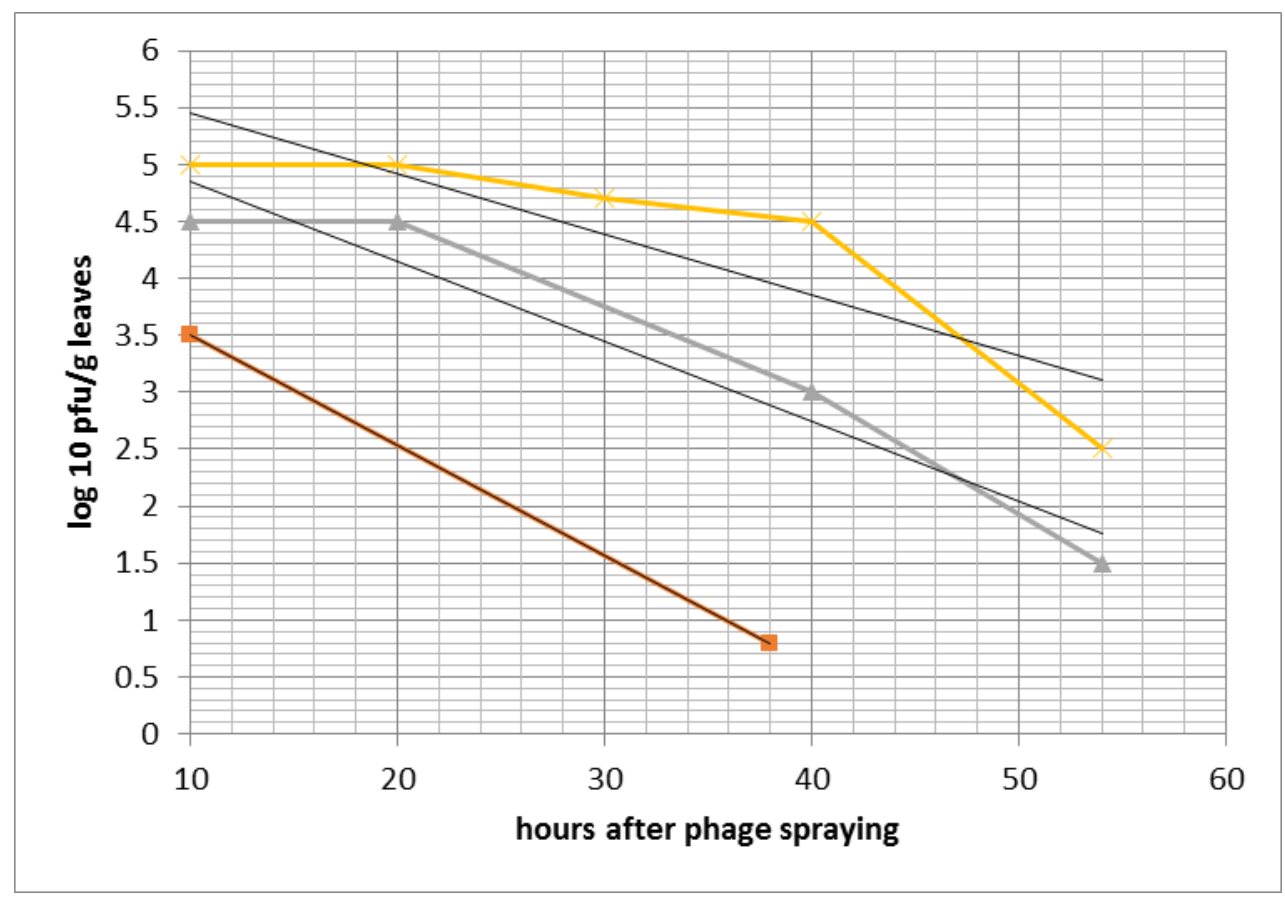

Hage without corn flour formulated page skim milk formulated pahge

Fig. 3: Longevity of formulated phages on pepper leaves inoculated with $X$. axonopodis $\mathrm{EG}$ under green house and open field.

\section{Discussion}

Bacterial halo blight of plants caused by $X$. axonopodis has been a considerable problem in Egypt. The disease symptoms in open field can show considerable variation at the most distractive where temperatures are moderate and abundant inoculum is available (Kucharek, 1994).

$X$. axonopodis EG was isolated from infected pepper plants and distinct halo blight disease in open field. Morphology of colonies were similar to the standard X. axonopodis isolates. Morphological and biochemical tests indicated that the isolated bacteria were attributed to Xanthomonadaceae family (Fourie, 1998 and Sahin and Miller 1996).

Bacteriophage specific for $X$. axonopodis were detected in infected pepper leaves and discrete halo blight disease. The crude phages suspension prepared from infected leaves and assayed by the over-layer agar method (Eman and Afaf, 2014 and Balogh and Jones 2003). Single plaque which has the same plaque morphology of each plaque isolate picked up to obtained single phage of each Ps. syringae isolate. The phage titer usually assayed by the double layer agar method. The bacteriophages exhibited a regular , irregular, hexagon outline and a short noncontracted or long contracted tail. The isolated phage was characterized with large head and short tail associated with cystoviridae family, morphologically.

One of the greatest challenges in using phages for plant disease control is their extremely short residual activity in the phyllosphere, several studies indicated that phage populations can drop to undetected levels hours after applications (Iriarte, et al., 2007). Phages treatment was effective only in the morning 
before down. The short residual activity of the control agents hindered the efficacy of

phage treatment when applied during day time. Phages are rapidly degraded in the greenhouse and open field and partially disappear from the pepper foliage about 2 days after application.

The results indicated that the efficacy of phages formulation by skim milk and corn flour could be increased phage protective and proper timing of application. Several protective formulation were identified in earlier studies (Balogh, 2002and Saccardi, et al.1993) and three of them were selected for disease control trials. These formulations increased the concentration of phage population 2 days after the application.

In this study, protective formulations increased the efficacy of phages treatments for disease control both in the greenhouse and in the open field. Skim milk gave the best results in greenhouse and open field followed by corn flour compared with unformulated phages. Despite the improved efficacy in disease control, none of these treatments achieved a significantly increase in yield. This could have been the result of the highly contagious nature of phage infection. Phages were detected in many untreated plots in the middle of the season in the spring field experiment in Quincy, and in all plots by the end of the growing season in the trail field experiment (Balogh, 2002).

Several alternative control methods have been investigated in recent years systemic acquired resistance (SAR) inducers (Qui, et al., 1997). Biological control of the disease has been attempted by using a nonpathogenic Xanthomonas campestris $p v$ vesicatoria T3 strain to antagonize the TLS strain (Liu, 1998) and with other antagonistic bacteria such as Pseudomonas putida B56 and Pseudomonas syringae Cit 7 (Swords, et al.,1996 and Wilson et al., 1997). Plant growth promoting rhizobaceria (PGPR1) that induce SAR have been successfully used for controlling bacterial speck of tomato (Ji et al., 2006). Another approach for biological control is the use of phages to control bacterial diseases. Phages have long been proposed as a plant disease control agent (Jones et al., 1998; 2004 and 2007) and have been used in several plant bacteria pathosystems (Coons, and Kotila, 1925 and Tanaka et al, 1990).

In field trails twice weekly early morning spray applications of mixture of four phages specific to $X$. campestris pv. vericateria reduced disease severity of bacterial spot on plants by an average of $17 \%$ whereas copper mancozeb application reduced disease severity only 11\% ( Bouzar, et. al. , 1999 and Flaherty, et al., 2000). The phage application in the late morning was ineffective for controlling of bacterial spots and speculated that phage endurance was significantly reduced. Viruses are very fragile and can't reside long on plant foliage because they are quickly eliminated by harmful environmental factors such as rain and sunlight UV (Mc Guire $\boldsymbol{e t}$ al., 2001 and Zaccordelli, et al., 1992).

\section{Conclusion}

In view of the obtained results it could be mentation that, two formulated phages $0.5 \%$ corn flour and $0.5 \%$ skim milk significantly increased phage longevity on pepper leaves surface and applied to control halo blight disease in open field. So, it could be recommended that these formulated phages may be used as a tool to efficient biocontrol of halo blight disease, to minimize the application of chemical control compounds. Therefore, reduce environmental pollution.

\section{References}

Balogh, B. 2002. Strategies for improving the efficacy of bacteriophage for controlling bacterial spot of tomato. M.S. Thesis University of Florida Gainesville.

Balogh, B. and Jones, J.B. 2003. Improved efficacy of newly formulated bacteriophages for management of bacterial spot on tomato. Plant disease. Vol. 87 (8) 944 - 954.

Bouzar,H.,Jones,J.B.; Stall,R.E.; Louws， F.J.; Schneider,M.; Rademaker,J.L.M.; de Bruijn, F.J.andJackson. L.E.1999. Multiphasic analysis of xanthomonads causing bacterial spot disease on tomato and pepper in the Caribbean and Central America: Evidence for common lineages within and between countries. Phytopathology 89:328-335

Coons, G.H. and Kotila, J.E. 1925. The transmissible lytic principle (bacteriophage) in relation to plant pathogens. Phytopatholical 15: $357-370$.

Eayre, C.G., Bartz, J.A. and Concelmo, D.E.1995. Bacteriophage of Erwinia cavotovora and Erwinia arenas isolated from fresh water lakes. Plant Dis., 79: 801-804.

Eman, O.Hassan and Afaf, Z.A., El-Menesy, S.M. 2014. Biocontrol of Halo Blight of Bean Caused by Pseudomonasphaseolicola.International Journal of Virology, 10: 235-242.

Flaherty, J.E.; Jones, J.B.; Harbough, B.K., Somodi, G.C. and Jackson, L.E. 2000. Control of bacterial spot on tomato in the greenhouse and field withH-mutant bacteriapage. Hortic. Sci.,35:882884

Fourie, D. (1998): Characterization of halo blight races on dry beans in South Africa. Plant Dis. 82: 307 - 310.Heringa, S.D.; Kim, J.; Jiang, X., Doyle, M.P. and Erickson, M.C. (2010): Use of a mixture of bacteriophages for biological control of Salmonella enterica strains in compost. 
Applied and Environmental Microbiology Vol. 76: (15): 5327 - 5332.

Iriarte, F.B., Balogh, B., Momol, M.T., Smith, L.M.L Wilson, M.A and Jones J.B. 2007. Factors affecting survival of bacteriophage on tomato leaf surfaces. Appl. Environ. Microbiol. 73: $1704-$ 1711.

Ji, P., Campbell, H.L., Kloepper, J.W., Jones, J.B., Suslow, T.V., and Wilson, M. 2006. Integrated biological control of bacterial speck and spot of tomato under field conditions using foliar biological control agents and plant growthpromoting rhizobacteria. Biol. Control. 36:358367

Jones, J.B.; Jackson, L.E.; Balogh, B.; Obradovic, A.; Iriarte, F.B. and Momol, M.T. (2007): Bacteriophages for plant disease control. Annual Review of Phytopathology 45: 245 - 262.

Jones, J.B. and K. Pernezny. 2003. Bacterial spot. Pages 6-7 in: Compendium of Pepper Diseases. K. Pernezny, P.D. Roberts, J.F. Murphy, and N.P. Goldberg, eds. American Phytopathological Society, St. Paul, MN.

Jones, J.B., Stall,R.E. and Bouzar,H. (1998). Diversity among xanthomonads pathogenic on pepper and tomato. Annual Review of Phytopathology 36:41-58.

Jones, J.B., Lacy, G.H.Bouzar, H. Stall, R.E.and Schaad,N.W.. (2004). Reclassification of the xanthomonads associated with bacterial spot disease of tomato and pepper. Systematic and Applied Microbiology 27: 755-762.

Kousik, C.S. and Ritchie,D.F. (1996). Race shift in Xanthomonas campestris pv. vesicatoria within a season in field-grown pepper. Phytopathology 86:952-958.

Kuchare, K.T. (1994). Plant pathology fact sheet: Bacteria spot of tomato and pepper. University of Florida, Institute of food and Agricultural Sciences. Plant Pathology Department Cooperative Extension Service Online. Online publication BODY - VH007.

Liu, T. (1998): Biological control of tomato bacterial spot with a important of Xanthomonas campestris pv vesicotoria $\mathrm{M}$. S. Thesis University of Florida Goinesville.

Louws, F.J., Wilson, M., Campbell, H.L., Cuppels, D.A.; Jones, J.B.; Shoemaker, D.B.; Sahin, F. and Miller, S.A. (2001). Field control of bacterial spot and bacterial speck of tomato using a plant activator. Plant Dis. 85:481 - 488.

Marco, G.M. and Stall, R.E. (1983): Control of bacteria spot of pepper initiated by strains of
Xanthomonas campestris pv vesicatoria that differ in sensitivity to copper. Plant Dis. 67: 779 -781 .

Mc Guire, M.R. Tamez-Guerra, P. Behle, R.W. and Streen, D.A. (2001): Comparative field stability of selected Entomapathologenic virus Formulations. J. Econ. Entomol. 94: 1037 - 1044

Obradovic, A.; Jones, I.B.; Momol, H.T., Olson, S.M.; King, P., C. and Balogh, B. (2002): Management of tomato bacterial spot in the field by foliar application of bacteriophages and SAR inductors (Abstr.) Phytopathology 92: 560.

Qui, D.; Wei, Z.M.; Bauer, D.W. and Beer, S.V. (1997): Treatment of tomato seeds with harpin enhances germination and growth and induces to ralstonina solanacearum (Abstract). Phytopathology 87: 580.

Saccardi, A.; Gambin, E.; Zaccardelli, M.; Barone, G. and Mazzucchi, U.(1993): Xanthomonas campestris pv. Pruni control trails with phage treatments on peaches in the orchard. Phytopathol. Mediterr. 32: 206 - 210.

Sahin, F. and Miller,S.A. (1996): Characterization of Ohio strains of Xanthomonas campestris pv. vesicatoria, causal agent of bacterial spot of pepper. Plant Disease 80:773-778.

Shaner, G. and Finney, R.E. (1977): The effect of nitrogen fertilization in the expression of slowmildewing resistance in Knox wheat. Phytopathology, 67, 1051-1056.

Swords, K.M.M., Dahlbeck, D.Kearney, B. Roy, M.and Staskawicz,B.J. (1996): Spontaneous and induced mutations in a single open reading frame to both virulence and avirulence in Xanthomonas campestris pv. vesicatoria avrBs2.

Tanaka, H.; Negishi H. and Maeda H. (1990): Control of tobacco bacterial wilt by an avirulent strain of Pseudomonas solanacearum M4S and its bacteriophages. Ann.Phytopathol.Soc. Jpn, 56:243-246.

Weller, D.M. (2007): Pseudomonas biocontrol agents of Soilborne Pathogens: Looking back over 30 years. Phytopathology 97: 250 - 256.

Wilson, M.; Campbell, H.L., Jones, J.B.; Suslow, T.V. and Cuppele, D.A. (1997): Biological control of bacterial speck of tomato (Abst.) Phytopathology (Abstract) 86, 549.

Zaccordelli, M.; Saccardi, A.; Gambin, E. and Mazzucchi, U. (1992): Xanthamonas campestris pv. Pruni bacteriophages on peach trees and their potential use for biological control. Phytopathol. Mediterr. 31, $133-140$. 


\title{
المقاومة الحيوية للزانثومونس أكسونويودز المسبية لمرض التبقع بواسطة إستخدام تحميلة الفاج .
}

\author{
طه عبده توفيق 1 و شيماء أحمد دسوقى 2

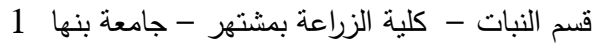 \\ قسم النبات - كلية العلوم - جامعة السويس 2
}

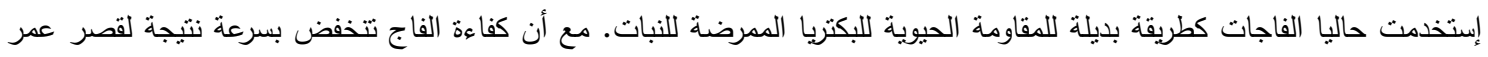

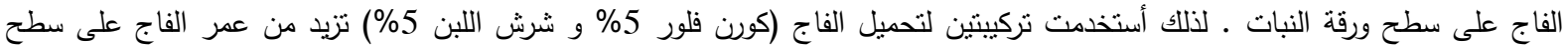

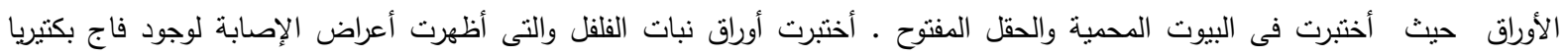
الزانثومونس المتخصص بواسطة إختبار البقعة أو الهالة ( البلاكات). وبطريقة البلاكات المنفردة أو البقعة قد عزلت الفاجات من أورات الفاق نبات الفات

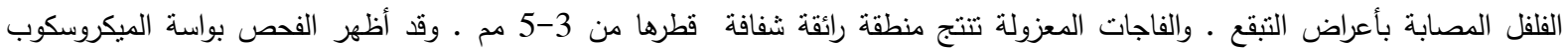

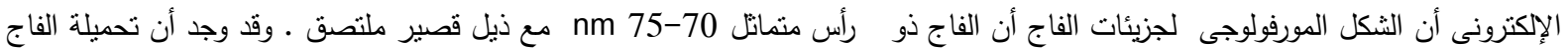

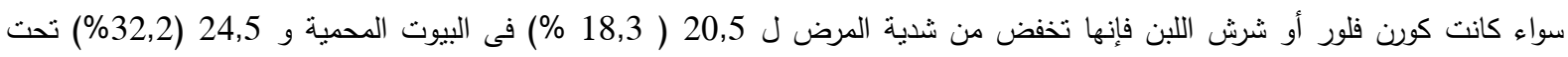

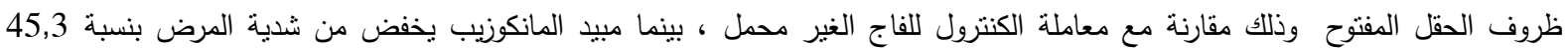

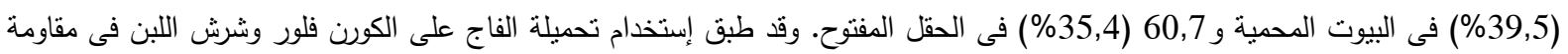

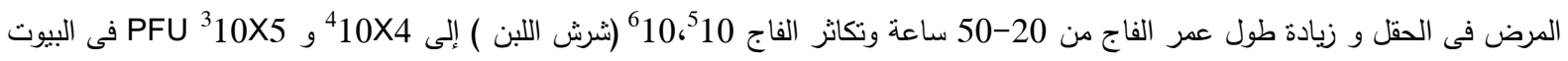

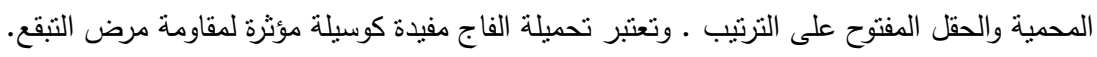

